\title{
The importance of medical devices in preventing and combating SARS-CoV-2 and cooperation between national regulators, academy and industry - Perspectives from the Portuguese reality
}

\author{
A importância dos dispositivos médicos na prevenção e combate ao SARS-CoV-2 e da cooperação \\ entre reguladores, academia e indústria nacional-Perspetivas da realidade portuguesa
}

\section{Isabel Maria Martins Portugal de Abreu}

Universidade Lusófona, Av Campo Grande, 376, 1749-024, Lisboa, Portugal

*corresponding author: isabel.portugal51@gmail.com

\begin{abstract}
In view of the scarcity of medical devices necessary to combat the outbreak crisis caused by the new SARS-CoV-2 coronavirus pandemic, an exceptional regime regarding applicable device conformity assessment procedures and market surveillance was established through Recommendation (EU) 2020/403 of the European Commission of 13 March. This was adopted by Portugal through the publication of Decree-Law no. 14-E / 2020 of 13 April.

Many guidelines were issued during the pandemic by INFARMED and with the cooperation of other national entities (Ministry of Economy, Ministry of Science, Technology and Higher Education, national Industry and General Directorate of Health) to support medical device manufacturers and importers. It is important that these guidelines are reflected in the development of the Portuguese medical device industry in order to promote its international recognition and to ease access to other medical markets.

A detailed analysis of all variables here included in this opinion article, together with some proposals, aims to promote a national strategic vision in the area of the development and production of medical devices, in order to enhance ideas and gains that resulted from these responses to the crisis, serving for future analysis to be published in due course.
\end{abstract}

Keywords: INFARMED, Medical Devices Legislation, COVID-19,SARS-CoV-2

\section{Resumo}

Face à crise instalada com o deflagrar da pandemia associada ao novo coronavírus SARS-CoV-2, ao nível de propagação do vírus e à escassez de dispositivos médicos necessários ao seu combate, foi estabelecido um regime excecional relativamente aos procedimentos de avaliação da conformidade e de fiscalização do mercado, aplicável a estes dispositivos, através da Recomendação (UE) 2020/403 da Comissão Europeia de13 março, que foi adotada por Portugal através da publicação do Decreto-Lei n. ${ }^{\circ}$ 14-E/2020 de 13 de abril.

É importante que a regular produção de orientações emanadas pelo INFARMED durante a pandemia e a cooperação de outras entidades nacionais (Ministério da Economia, Ministério da Ciência, Tecnologia e Ensino Superior e Indústria Nacional e Direção Geral de Saúde), de apoio aos fabricantes e importadores, se reflitam no desenvolvimento do sistema produtivo português, permitindo promover o reconhecimento internacional da indústria nacional e o fácil acesso a outros mercados.

Uma análise detalhada de todas as variáveis que inclúi neste artigo de opinião e a apresentação de propostas, na perspetiva da definição de uma visão estratégica nacional, na área do desenvolvimento e produção de dispositivos médicos, de forma a potenciar as ideias e ganhos que resultaram da resposta à crise, será objeto de estudo a publicar oportunamente.

\section{Palavras-chave: INFARMED. Legislação Dispositivos Médicos, COVID-19, SARS-CoV-2}

This is an opinion article, under the full responsibility of the author, based on the appreciation of the situation occurred with the scarcity of medical devices for the prevention and combat of SARS-CoV-2 and

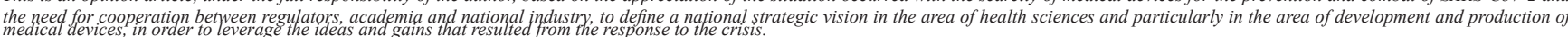

Trata-se de um artigo de opinião, da total responsabilidade do autor, baseado na apreciação da situação ocorrida com a escassez de dispositivos médicos para a prevenção e combate ao SARS-CoV-2 e a necessidade de cooperação entre reguladores, academia e indústria nacional, para a definição de uma visão estratégica nacional na área das ciências de saúde e em particular na área do desenvolvimento e produção de dipositivos médicos, de forma a potenciar as ideias e ganhos que resultaram da resposta à crise. 


\section{Introduction}

Medical devices are a medical technology with an enormous relevance in the provision of healthcare for the benefit of citizens. Used throughout the life of human beings, they are crucial in the diagnosis, prevention, monitoring and treatment of diseases and attenuation or compensation of deficiencies. They can save lives, improve health, and contribute to sustainable health care.

There are more than 500,000 medical technologies including, among many others, syringes, glasses, latex gloves, wheelchairs, pregnancy tests, hearing aids, implantable devices such as heart valves and pacemakers, surgical masks, ventilators, coronary stents, hydroxyhepatitis nanostructures for knee prostheses, hemostatics with human thrombin, technologies that allow computers to imitate human intelligence, screening tests, and genetic mutation tests.

Since the 1980s, medical devices have been strictly regulated in the European Union by Community Directives (1-8) which regulate the safety and performance of devices, covering all stages of their life cycle: design, manufacture, conformity assessment, placing on the market, post-placing monitoring and surveillance.

Systematically adapted to the state of the art, characterized by a constant flow of innovations and also by the similarity, in some cases, to medicines, increasingly demanding requirements have been introduced over the years, supported by studies and negotiations between stakeholders, imposing procedures that give consumers the guarantee of safety, and adequate functional and clinical performance of the various medical devices.

The changes have focused mainly on the designation and monitoring of the Notified Bodies (ONs); Clinical Evaluation and Post-Market Clinical Follow-up and Clinical Investigation; Conformity Assessment; Market Surveillance; Traceability; Transparency and Communication and the Coordination and Cooperation of the Competent Authorities.

Over the years, these factors have manifested themselves as critical points of the medical device regulatory system.

The great diversity of products, with different technologies, from the simplest to the most complex, and with different degrees of risk for users, has led to the drafting of the Community Directives for medical

\section{Introdução}

Os dispositivos médicos são uma tecnologia médica com uma enorme relevância na prestação de cuidados de saúde, em benefício dos cidadãos. Utilizados ao longo da vida dos seres humanos, são cruciais no diagnóstico, prevenção, monitorização e tratamento de doenças e atenuação ou compensação de deficiências. Podem salvar vidas, melhorar a saúde e contribuir para cuidados de saúde sustentáveis.

Existem mais de 500.000 tecnologias médicas onde, entre muitos outros, se incluem seringas, óculos, luvas de látex, cadeiras de rodas, testes de gravidez, aparelhos auditivos, dispositivos implantáveis como válvulas cardíacas e pacemakers, máscaras cirúrgicas, ventiladores, stents coronários, nano-estruturas de hidroxihepatite para próteses do joelho, hemostáticos com trombina humana, tecnologias que permitem aos computadores imitar a inteligência humana, testes de triagem e testes de mutação genética.

Na União Europeia, os dipositivos médicos são, desde a década de 80 , rigorosamente regulamentados por Diretivas Comunitárias (1-8), que regulam a segurança e o desempenho dos dispositivos, abrangendo todas as fases do seu ciclo de vida: conceção, fabrico, avaliação da conformidade, colocação no mercado, monitorização pós colocação no mercado e vigilância.

Sistematicamente adaptados ao estado da arte, caracterizado por um fluxo constante de inovações e também pela similitude, nalguns casos, aos medicamentos, têm vindo a ser introduzidos ao longo dos anos requisitos cada vez mais exigentes, suportados em estudos e negociações entre as partes interessadas, impondo procedimentos que dão aos consumidores a garantia de segurança e de adequado desempenho funcional e clínico dos diversos dispositivos médicos.

As alterações têm-se focado principalmente na designação e monitorização dos Organismos Notificados (ONs); na Avaliação Clínica Pré e Pós Mercado e Investigação Clínica; na Avaliação da Conformidade; na Fiscalização do Mercado; na Rastreabilidade; na Transparência e Comunicação e na Coordenação e Cooperação das Autoridades Competentes.

Estes fatores têm - se manifestado ao longo dos anos como os pontos críticos do sistema regulamentar dos dispositivos médicos.

A grande diversidade de produtos, com diferentes tecnologias, das mais simples às mais complexas e com diferentes graus de risco para os utilizadores, levou a que 
devices based on the system for drafting the Community technical harmonization directives (9). This system is based on the definition of essential requirements and the use of harmonized standards, providing for the implementation of procedures for assessing the conformity of products with the specifications of the applicable legislation and the affixing of $\mathrm{CE}$ marking to these products.

This is an opinion article, under the full responsibility of the author, based on the appreciation of the situation that occurred with the scarcity of medical devices for the prevention and combat of SARS-CoV-2 and the need for cooperation between regulators, academia, and national industry. It is meant to help define a national strategic vision in the area of health sciences and particularly in the area of development and production of medical devices in order to leverage the ideas and gains that resulted from the national response to the crisis.

\section{Entities involved in the life cycle of medical devices}

Entities with different responsibilities and functions are defined and intervene in a coordinated way in the life cycle of medical devices, creating synergies of competences that reinforce each other as the best way to guarantee the efficacy and effectiveness of the adopted regulatory system (1-8), allowing the safe use of medical devices. These entities include the Manufacturer, the Notified Body, the Designating Authority for Notified Bodies, and the Competent Authority.

The Manufacturer is responsible for quality assurance, safety, and performance of products throughout their life cycle, from design, qualification and risk classification, to conformity assessment, manufacture, packaging, labeling, instructions for use, CE marking, placing on the market, putting into service, surveillance and withdrawal of the device from the market. These responsibilities are expressed in the Declaration of Conformity that the Manufacturer must establish for all the devices that he manufactures, and this Declaration must be made available to the notified bodies and the national competent authorities.

The manufacturer's obligations are reinforced with the new Regulations (7-8), including additional requirements regarding the pre and post marketing phases, namely:

- the largest investment in the evaluation of data / studies / clinical investigations in the pre and post market, in ensuring that the rules applicable to a elaboração das Diretivas Comunitárias dos dispositivos médicos se baseasse no sistema de elaboração das diretivas de harmonização técnica comunitária (9), o qual assenta na definição dos requisitos essenciais e no recurso às normas harmonizadas, prevendo a implementação de procedimentos de avaliação de conformidade dos produtos com as especificações da legislação aplicável e a aposição da marcação CE a esses produtos.

O presente artigo de opinião, da total responsabilidade do autor, baseia-se na apreciação da situação ocorrida com a escassez de dispositivos médicos para a prevenção e combate ao SARS-CoV-2 e a necessidade de cooperação entre reguladores, academia e indústria nacional. O objetivo é contribuir para a definição de uma visão estratégica nacional na área das ciências de saúde e em particular na área do desenvolvimento e produção de dipositivos médicos, de forma a potenciar as ideias e ganhos que resultaram da resposta nacional à crise.

\section{Entidades intervenientes no ciclo de vida dos dispositivos médicos}

São definidas as entidades que, com diferentes responsabilidades e funções, intervêm coordenadamente no ciclo de vida dos dispositivos médicos criando sinergias de competências que se reforçam mutuamente como a melhor via para garantir a eficácia e a efetividade do sistema regulamentar adotado (1-8), permitindo a utilização segura dos dispositivos médicos.

Estas entidades incluem o Fabricante, o Organismo Notificado, a Autoridade de Designação para os Organismos Notificados e a Autoridade Competente.

O Fabricante é o responsável pela garantia da qualidade, da segurança e do desempenho dos produtos durante todo o seu ciclo de vida, desde a conceção, à qualificação e classificação de risco, à avaliação da conformidade, ao fabrico, à embalagem, à rotulagem, às instruções de utilização, à marcação $\mathrm{CE}$, à colocação no mercado, à entrada em serviço, à vigilância e à retirada do dispositivo do mercado. Esta Responsabilidade está expressa na Declaração de Conformidade que o Fabricante tem de redigir para todos os dispositivos que fabrica e que terá de ser disponibilizada aos organismos notificados e às autoridades competentes nacionais.

As obrigações do fabricante são reforçadas com os novos Regulamentos (7-8) incluindo requisitos adicionais relativamente às fases da pré e pós comercialização, nomeadamente: 
clinical investigations must be compatible with the international guidelines established in this field, such as the international standard ISO 14155: 2011 on good clinical practices for the clinical investigation of medical devices in humans in addition to compliance with the most recent version of the World Medical Association's Helsinki Declaration on "Ethical principles applicable to medical research in humans;"

- mandatory scrutiny by expert panels of reports of their clinical assessment assessments for Class III devices and certain Class IIb devices;

- post-market clinical follow-up, in which a summary of the safety and clinical performance of implantable devices and class III devices is mandatory;

- the performance of an active role during the postmarketing phase, gathering information arising from the experience acquired with its devices after the respective commercialization in a systematic and active way, in view of updating its technical documentation regarding the risk assessment and the clinical evaluation and in cooperation with the competent national authorities in charge of market surveillance and surveillance activities.

Notified Bodies are the entities responsible for carrying out tasks related to the scientific and technical evaluation of medical devices, validating the conformity assessment procedures implemented by the manufacturer and adapted to each type of device, based on the demonstration of compliance with safety, performance, design, and manufacture.

Considered one of the fundamental elements for guaranteeing confidence in the system, the activity of the Notified Bodies has been systematically reinforced with the introduction of detailed and rigorous criteria, both with regard to their designation and monitoring and to the competence criteria that they must demonstrate.

A conformity assessment body that is a candidate for a notified body is subject to a designation process by the EU Member State where it is based after evidence of its competence to perform the tasks defined in each Directive or Regulation has been demonstrated and verified for the proposed conformity assessment devices or procedures. The competency assessment is carried out by the National Designation Authority and by experts from two Designating Authorities in other member states and the European Commission.
- maior investimento na avaliação dos dados/estudos/ investigações clínicas no pré e pós mercado, na garantia de que as regras aplicáveis às investigações clínicas deverão ser compatíveis com as orientações internacionais consagradas neste domínio, tais como a norma internacional ISO 14155:2011 sobre boas práticas clínicas para a investigação clínica de dispositivos médicos em seres humanos para além da conformidade com a versão mais recente da Declaração de Helsínquia da Associação Médica Mundial sobre "Princípios éticos aplicáveis à investigação médica em seres humanos;"

- obrigatoriedade de escrutínio por painéis de peritos dos relatórios das suas avaliações da avaliação clínica para dispositivos da classe III e de certos dispositivos da classe IIb;

- acompanhamento clínico pós-comercialização, e a obrigatoriedade de disponibilizar um resumo da segurança e do desempenho clínico dos dispositivos implantáveis e dos dispositivos da classe III;

- desempenho de um papel ativo durante a fase de póscomercialização, reunindo de forma sistemática e ativa informações decorrentes da experiência adquirida com os seus dispositivos após a respetiva comercialização, tendo em vista a atualização da sua documentação técnica referente à avaliação dos riscos e à avaliação clínica e na cooperação com as autoridades nacionais competentes encarregadas das atividades de vigilância e fiscalização do mercado.

Os Organismos Notificados são as entidades responsáveis pela execução das tarefas relativas à avaliação técnico científico dos dispositivos médicos, validando os procedimentos de avaliação da conformidade implementados pelo fabricante, adaptados a cada tipo de dispositivo, alicerçada na demonstração da conformidade de requisitos de segurança, desempenho. conceção e fabrico.

Considerados uma das peças fundamentais para a garantia da confiança no sistema, a atividade dos Organismos Notificados tem sido sistematicamente reforçada com a introdução de critérios circunstanciados e rigorosos, quer no que se refere à sua designação e monitorização quer aos critérios de competência que deverão demonstrar.

Um organismo de avaliação da conformidade candidato a organismo notificado é sujeito a um processo de designação por parte do Estado-membro da União Europeia onde está sediado, após ter sido demonstrada e verificada a evidência da sua competência para realizar 
Since 1995, INFARMED has been the Designating Authority for Notified Bodies based in Portugal (3) within the scope of the medical device directives, responsible for the assessment at the time of their designation and periodic reassignment, as well as for monitoring performance INFARMED has made an admirable effort over the years, investing in continuous improvement, acquiring the experience and knowledge necessary for the proper exercise of this function, taking into account the type of products concerned and the approximation of evaluation methodologies between the sectors of medical devices and medicines.

The requirements in terms of designation criteria have been reinforced in the recently published Regulations (7-8). In this context, these Regulations adapt the requirements established in 2013 through Implementing Regulation (EU) No 920/2013 of the Commission, of 24 September 2013, published following some media cases such as that of breast implants of the PIP Implants brand, and reintroduces the mandatory European joint assessment procedure for notified bodies, either at the time of their designation or in their periodic reassignment.

It should also be noted that the authorities responsible for the notified bodies should actively participate in the careful assessment of the manufacturers' technical documentation, based on a sampling of the relevant documentation and in particular the documentation related to the clinical assessment, whenever justified by the risk of the devices involved.

Finally, but with increasingly relevant requirements, the National Competent Authorities (3-5) are assigned the functions of market surveillance and surveillance, ensuring that devices placed on the national market do not compromise the health and safety of consumers, patients, users, and third parties. However, the National Competent Authorities may also be called upon to intervene in the design and manufacture phase of the device, in the evaluation of clinical investigations, for high-risk devices, as well as in exceptional authorizations for the use of devices which, although not complying with the conformity assessment procedures, prove to be necessary in terms of public health. as tarefas definidas em cada Diretiva ou Regulamento, para os dipositivos ou procedimentos de avaliação da conformidade a que se propõe. A avaliação da competência é realizada pela Autoridade de Designação Nacional e por peritos de duas autoridades de designação de outros Estados membros e da Comissão Europeia.

O INFARMED é, desde o ano de 1995, a Autoridade de Designação para os Organismos Notificados sediados em Portugal (3), no âmbito das diretivas dos dispositivos médicos, responsável pela avaliação no momento da sua designação e redesignação periódica, bem como pela monitorização do seu desempenho. $\mathrm{O}$ INFARMED tem ao longo dos anos desenvolvido um esforço admirável, apostando na melhoria contínua, adquirindo a experiência e o conhecimento necessários ao bom exercício desta função, tendo em atenção o tipo de produtos em causa e a aproximação das metodologias de avaliação entre os sectores dos dispositivos médicos e dos medicamentos.

As exigências em termos de critérios de designação foram reforçadas nos Regulamentos recentemente publicados (7-8). Nesse contexto estes Regulamentos adequam os requisitos estabelecidos em 2013 através do Regulamento de Execução (UE) N.o 920/2013 da Comissão, de 24 de setembro de 2013, publicado na sequência de alguns casos mediáticos como foi o caso das próteses mamárias da marca PIP Implants, e reintroduz a obrigatoriedade de procedimento europeu de avaliação conjunta aos Organismos notificados, quer no momento da sua designação, quer na sua redesignação periódica.

De realçar ainda que as autoridades responsáveis pelos organismos notificados deverão participar ativamente na avaliação criteriosa da documentação técnica dos fabricantes, assente numa amostragem da documentação relevante e em particular da documentação relativa à avaliação clínica, sempre que o risco dos dispositivos envolvidos o justifique.

Por último, mas com exigências cada vez mais relevantes, as Autoridades Competentes Nacionais (3-5), a quem são atribuídas as funções de fiscalização e vigilância do mercado, garantindo que os dispositivos colocados no mercado nacional não comprometem a saúde e a segurança dos doentes, dos utilizadores e de terceiros. Contudo, as Autoridades Competentes Nacionais podem ser também chamadas a intervir na fase de conceção e fabrico do dispositivo, na avaliação das investigações clínicas, para dispositivos de risco elevado e também nas autorizações excecionais da 
Also, according to the new Regulations, with regard to Class III implantable medical devices and Class IIb active medical devices intended for the administration and/or disposal of medicines, competent authorities must be aware of the certificates issued by the notified bodies, following a conformity assessment procedure that involves the obligation to consult a panel of experts regarding clinical evaluation.

It is the responsibility of the National Competent Authorities to activate the safeguard clause, requiring the withdrawal of medical devices from the market which may compromise the health and safety of the patient or third parties, even if correctly placed on the market and used in accordance with the purpose for which they are intended.

Since 1995, INFARMED has been the Competent Authority for medical devices (3), extended to include medical devices for in vitro diagnostics in August 2000. Subsequently in March 2006, through Decree-Law no. $76 / 2006$ (10), as most European Union member states (around 90\%), in which the regulation of medical devices is carried out by a single Institution, usually the Competent Authority in matters of medicines, INFARMED was named as the Competent Authority for all types of medical devices (active implantable medical devices, medical devices and in vitro diagnostic medical devices).

As stated in the aforementioned Decree-Law (10), the designation of INFARMED as the authority responsible for the regulation of all medical devices, was justified "by the existence of multiple border products whose classification will be carried out more rigorously by the competent authority in terms of medicines and because the restructuring of this sector is the best way to contribute to a more modern and developed health system, contributing to better protection and guarantee of public health with regard to the placing on the market and use of medical devices." utilização de dispositivos, que apesar de não cumprirem os procedimentos de avaliação da conformidade, demostram ser necessários em termos de saúde pública.

Também, de acordo com os novos Regulamentos, no que se refere aos dispositivos implantáveis da classe III e aos dispositivos ativos da classe IIb destinados à administração e/ou à eliminação de medicamentos, as autoridades competentes têm de ter conhecimento dos certificados emitidos pelos organismos notificados, na sequência de um procedimento de avaliação da conformidade que tenha envolvido a obrigatoriedade de consulta a um painel de peritos, relativamente à avaliação clínica.

É responsabilidade das Autoridades Competentes Nacionais acionar a cláusula de salvaguarda, exigindo a retirada do mercado dos dispositivos médicos que, ainda que corretamente colocados no mercado e utilizados de acordo com o fim a que se destinam, possam comprometer a saúde e segurança do doente ou de terceiros.

O INFARMED é desde 1995 a Autoridade Competente para os dispositivos médicos (3), competência alargada aos Dispositivos médicos para diagnóstico in vitro em Agosto de 2000. Posteriormente em Março de 2006, através do Decreto-Lei n. ${ }^{\circ}$ 76/2006 (10), o INFARMED, à semelhança do que se passa na generalidade dos Estados membros da União Europeia (cerca de $90 \%$,), em que a regulação dos dispositivos médicos é cometida a uma única instituição, normalmente a Autoridade Competente em matéria de medicamentos, o INFARMED é Autoridade Competente para todos os tipos de dipositivos médicos (dispositivos médicos implantáveis ativos, dispositivos médicos e Dispositivos médicos para diagnóstico in vitro).

Conforme consta do referido Decreto-Lei (10) a designação do INFARMED como autoridade responsável pela regulação para todos os dispositivos médicos, justificou - se "pela existência de múltiplos produtos de fronteira cuja classificação será efetuada com maior rigor pela autoridade competente em matéria de medicamentos e porque a reestruturação deste sector é a melhor forma de contribuir para um sistema de saúde mais moderno e desenvolvido, contribuindo para uma melhor proteção e garantia da saúde pública no que toca à colocação no mercado e utilização de dispositivos médicos". 


\section{Medical devices and the pandemic}

The importance assumed by different types of medical devices in the fight against SARS-CoV-2, (ventilators, surgical masks, surgical gowns, sterile and nonsterile single-use gloves, cowls, single-use caps, cover boots and shoes, cuffs and swabs, tests used to detect the presence or previous exposure to the virus) and the responsiveness of INFARMED, in addition to other national entities (DGS, ASAE, IPQ), showed the strength and competence of the structure that is responsible for ensuring the safe use of medical devices in Portugal.

In view of the installed crisis and the scarcity of medical devices, Portugal adopted the principles of Commission Recommendation (EU) 2020/403 of 13 March 2020 (11), through the publication of DecreeLaw no. 14- E / 2020 of April 13th (12), in which, for exceptional cases, on a temporary basis and with the objective of supporting efforts to ensure the supply of medical devices and Personal Protective Equipment (PPE), if it proceeded to streamline, simplify or even to the derogation from the conformity assessment procedures, provided that the minimum health and safety requirements were guaranteed.

The timely production of nine guidelines to support manufacturers and importers, reflecting demanding criteria in terms of quality, safety, and performance assessment of missing medical devices, supported by competent national experts, highlighted the capacity and reinforcement of confidence in the authority that regulates this sector within Portugal.

The procedures required for the manufacture of devices covered by Decree-Law $n^{\circ} 14-E / 2020$ (12), although simplified and flexible, do not dispense with demonstrating compliance with the essential safety and performance requirements established in the applicable harmonized legislation.

\section{Masks for clinical use}

Among the guidelines produced on the Import and Manufacture of Medical Devices and Personal Protective Equipment in the context of the COVID-19 Pandemic (13-23), one is focused on masks for clinical use (16), which are considered low risk devices. One statement included is that "the responsibility for the conformity of these masks with the requirements to be defined will rest with the manufacturer, who must

\section{Os dipositivos médicos e a pandemia}

A importância assumida por diferentes tipos de dispositivos médicos no combate ao SARS-CoV-2, (ventiladores, máscaras cirúrgicas, batas cirúrgicas, luvas de uso único esterilizadas e não esterilizadas, cogulas, toucas de uso único, proteção de calçado, manguitos e zaragatoas, testes utilizados na deteção da presença ou na exposição anterior ao vírus) e a capacidade de resposta do INFARMED, para além de outras entidades nacionais (DGS, ASAE, IPQ), veio evidenciar a robustez e a competência da estrutura que em Portugal é responsável pela garantia da utilização segura dos dispositivos médicos.

Faceàcriseinstalada eà escassezdedispositivosmédicos, Portugal adotou os princípios da Recomendação da Comissão (UE) 2020/403 da Comissão, de 13 de março de 2020 (11), através da publicação do Decreto-Lei n. ${ }^{\circ} 14-E / 2020$ de 13 de abril (12), em que, para casos excecionais, de forma temporária e com o objetivo de apoiar os esforços destinados a garantir o fornecimento de dispositivos médicos e de Equipamentos de Proteção Individual (EPIs), se procedesse à agilização, à simplificação ou até mesmo à derrogação dos procedimentos de avaliação de conformidade, desde que fossem garantidos os requisitos mínimos de saúde e segurança.

A produção atempada de nove orientações de apoio aos fabricantes e importadores, refletindo critérios de exigência, em termos avaliação de qualidade, de segurança e de desempenho dos dispositivos médicos em falta, apoiada por peritos nacionais competentes, evidenciou a capacidade e o reforço da confiança na autoridade que em Portugal regula este setor.

Os procedimentos exigidos para o fabrico de dispositivos abrangidos pelo Decreto-Lei n. ${ }^{\circ} 14-\mathrm{E} / 2020$ (12), ainda que simplificados e flexíveis, não dispensam a demonstração do cumprimento dos requisitos essenciais de segurança e desempenho estabelecidos na legislação harmonizada aplicável.

\section{Máscaras de uso clínico}

Nas orientações produzidas sobre a Importação e Fabrico de Dispositivos Médicos e Equipamentos de Proteção Individual no contexto da Pandemia COVID-19 (1323), focando-me em particular no que diz respeito a máscaras de uso clínico (16) dipositivos de baixo risco, está incluída a informação de que "a responsabilidade da conformidade dessas máscaras com os requisitos a definir recairá no fabricante, devendo este escolher matérias-primas adequadas, conceber, fabricar e 
choose suitable raw materials, design, manufacture and label the masks so that they comply with the defined requirements, as well as test them in accordance with the applicable normative references, in a laboratory recognized for the purpose."

Performance characteristics are included, namely bacterial filtration efficiency, differential pressure (mask permeability to air), splash resistance and microbial cleaning (bioburden), as well as the identification of requirements and Technical Specifications (Harmonized Standards or standards equivalent international standards) which prove the conformity of the devices with the essential requirements.

All information related to the raw materials, the description of the manufacturing process, theinformation to be provided with the product, and the reports of the tests carried out and of the product's conformity (issued by a recognized, accredited laboratory for the indicated methods), appear in the technical file of the product prepared by the manufacturer and which must be submitted to INFARMED for assessment prior to placing on the market.

\section{Swabs}

In relation to swabs (19), the same guidelines also define means of transport, medical devices for in vitro diagnosis, which manufacturers must, "observing the normative references, prepare an evaluation report for safety and performance requirements, and photographs of the product (where the place where the lot is affixed, identification of the product and the manufacturer is visible)".

The technical specifications that must be followed to ensure quality, safety, and good functional performance are also related to promote their safe use, specifically: "Sterile swab for collection of exudate from the nasopharynx, flocculated, with plastic handle and tube with a cover with $2-3 \mathrm{ml}$ of medium for transport, detection and culture of viruses; The medium for transport must be: Hank's, with HEPES, gelatin, BSA, sucrose, and antibiotics; The swab should be of the "flocked" type and slim, with a breaking point and a tube with an adequate medium for transport; The presentation must be in an individual set of swabs and tubes with the medium for transport; The tip should be made of synthetic material such as dacron or rayon, not cotton." rotular as máscaras de forma a que estas cumpram com os requisitos definidos, assim como testá-las de acordo com os referenciais normativos aplicáveis, em laboratório reconhecido para o efeito".

Incluem as características de desempenho, nomeadamente a eficiência de filtração bacteriana, a pressão diferencial (permeabilidade da máscara ao ar), a resistência aos salpicos e a limpeza microbiana (bioburden) e também a identificação dos requisitos e das especificações técnicas (Normas Harmonizadas ou normas internacionais equivalentes reconhecidas), que comprovam a conformidade dos dispositivos com os requisitos essenciais.

Todas as informações relativas à matéria-prima, à descrição do processo de fabrico, à informação a fornecer com o produto e aos relatórios dos ensaios realizados e da conformidade do produto, emitidos por laboratório reconhecido, nomeadamente os laboratórios acreditados para os métodos indicados, consta de dossier técnico do produto, elaborado pelo fabricante e que tem de ser submetido ao INFARMED, para apreciação previamente à colocação no mercado.

\section{Zaragatoas}

As mesmas orientações definem também, no que respeita às zaragatoas (19) com meio para transporte, dispositivos médicos para diagnóstico in vitro, que os fabricantes devem, "observados os referenciais normativos, elaborar relatório de avaliação dos requisitos de segurança e desempenho, e fotografias do produto (em que seja visível o local de aposição do lote, identificação do produto e do fabricante".

Estão ainda identificadas as especificações técnicas que devem ser seguidas para garantir a qualidade, a segurança e o bom desempenho funcional, essenciais para a sua utilização segura: "Zaragatoa estéril para colheita de exsudado da nasofaringe, floculada, com cabo plástico e tubo com tampa com 2-3 $\mathrm{ml}$ de meio para transporte, deteção e cultura de vírus; $\mathrm{O}$ meio de transporte deverá ser: Hank's, com HEPES, gelatina, BSA, sacarose e antibióticos; A zaragatoa deverá ser de tipo "flocked" e fina, com ponto de quebra e tubo com meio de transporte adequado; A apresentação deverá ser em conjunto individual de zaragatoa e tubo com meio de transporte; A ponta deverá ser de material sintético tipo dracon ou rayon, não algodão. 
All information regarding the raw material, the description of the manufacturing process, the information to be provided with the product and the reports of the tests carried out and the product's conformity, issued by a recognized, accredited laboratory for the indicated methods, must appear in the technical file of the product prepared by the manufacturer and submitted to INFARMED for assessment prior to placing on the market.

\section{Ventilators}

It is also important to highlight the guidelines produced in the scope of ventilators (ventilator for intensive care, ventilators for non-critical care, ventilators for emergency and transport) (24), accessories, and parts or components.

The intervention of a notified body is required to carry out the technical, scientific evaluation of these medical devices, considered to be high risk, and to authorize the affixing of the CE marking under a general system of market placement. INFARMED, as other similar Competent Authorities, adopted the derogation procedure recommended by the European Commission (Commission Recommendation (EU) 2020/403, of 13 March), assuming the role of an evaluator as a mechanism to allow the access and use of devices for which CE marking is not required, supported by experts from the various fields of knowledge.

The scarcity of the market does not justify disrespect for non-compliance with the implementation of procedures that include strict criteria and guarantee product safety, demonstrating that the benefit outweighs the risk and that, as defined in the guidelines issued by INFARMED, are related to:

- The degree of criticality of the use of the device to protect individual and public health;

- The information collected by the market surveillance and / or surveillance system;

- The availability of alternative equipment / therapies considered adequate and in accordance with European legislation;

- The availability of documentation of compliance with harmonized standards or other specific technical solutions that guarantee compliance with the applicable essential requirements, established in the Medical devices directives;

- The availability of reports of tests carried out by
Todas as informações relativas à matéria-prima, à descrição do processo de fabrico, à informação a fornecer com o produto e aos relatórios dos ensaios realizados e da conformidade do produto, emitidos por laboratório reconhecido, nomeadamente os laboratórios acreditados para os métodos indicados, consta de dossier técnico do produto, elaborado pelo fabricante e que tem de ser submetido ao INFARMED, para apreciação previamente à colocação no mercado

\section{Ventiladores}

É importante também realçar as orientações produzidas no âmbito dos ventiladores (ventilador para cuidados intensivos, ventiladores para cuidados não críticos, ventiladores para emergência e transporte) (24), acessórios e partes ou componentes.

Para estes dispositivos, considerados de elevado risco, em que em situação de regime geral de colocação no mercado, é exigida a intervenção de um organismo notificado para efetuar a avaliação técnico científico dos dispositivos médicos e autorizar a aposição da marcação CE, o INFARMED, assim como outras Autoridades Competentes congéneres, adotou o procedimento de derrogação recomendado pela Comissão Europeia (Recomendação (UE) 2020/403 da Comissão, de 13 de março), assumindo o papel de avaliador, como mecanismo que permitiu o acesso e a utilização de dispositivos para os quais não é exigida a marcação $\mathrm{CE}$, apoiado por peritos das várias áreas do saber.

A escassez do mercado não justifica o desrespeito pelo não cumprimento da implementação de procedimentos que incluam critérios rigorosos, garante da segurança dos produtos, que demonstrem que o beneficio superior ao risco e que, tal como definido nas orientações emanadas pelo INFARMED, se relacionam com:

- O grau de criticidade do uso do dispositivo para a proteção da saúde individual e pública;

- A informação recolhida pelo sistema de vigilância e / ou fiscalização do mercado.

- A disponibilidade de equipamentos/terapêuticas alternativas consideradas adequadas e concordantes com a legislação europeia;

- A disponibilidade de documentação de conformidade com normas harmonizadas ou outras soluções técnicas específicas que garantam o cumprimento dos requisitos essenciais aplicáveis, estabelecidos na DDM;

- A disponibilidade de relatórios dos testes realizados por entidades competentes. 
competent entities.

For this purpose, the guidelines present (in detail) the characterization of different scenarios applicable to the activity of the manufacturers and the documentation they must present, namely regarding the essential requirements of safety and performance and of design and manufacture, including labeling and primary packaging and the technical specifications appropriate to the presumption of conformity with these requirements.

All information is available to the public on the INFARMED website (25). Additionally, guidelines and opinions are available to the public on the European Commission website (26), and, only for medical supplies, a list of harmonized standards for certain types of medical devices are freely available on CEN national members websites (27)

\section{Coordination and Cooperation}

The outbreak of the pandemic and the scarcity of medical devices in the national market have shown that there is a capacity for research, development, and production of these types of products within Portugal. There were many responses to support the health of the population from both academia and the national industry, however, we also found that not every group was prepared to understand and respect the required regulatory demands for medical devices to safeguard public health.

The critical role of INFARMED in coordinating the initiatives and activities developed by the various actors should be noted, ensuring that they were ruled by the highest quality standards, thus guaranteeing a permanently high level of protection of the health and safety of the national market.

\section{Conclusion}

The streamlining, simplification, and derogation of the conformity assessment procedures provided within Commission Recommendation (EU) 2020/403 and in Decree-Law no. 14-E / 2020 applies only in exceptional cases and in cases of devices placed on the national market.

Within a maximum period of six months, manufacturers must decide whether they want to place these products on the market in accordance with European Union
Para este efeito as orientações apresentam detalhadamente a caracterização de diferentes cenários aplicáveis à atividade dos fabricantes e a documentação que deverão apresentar, nomeadamente no que diz respeito aos requisitos essenciais de segurança e desempenho e de conceção e fabrico, incluindo a rotulagem e embalagem primária e as Especificações técnicas adequadas à presunção da conformidade com esses requisitos.

Toda a informação se encontra disponível ao público, no site do INFARMED (25). Também no site da Comissão Europeia se encontram disponíveis ao público guidelines e pareceres (26) e a lista de normas harmonizadas, para certos tipos de dispositivos médicos (27), excecionalmente disponibilizadas gratuitamente aos fornecedores de dispositivos médicos.

\section{Coordenação e Cooperação}

O deflagrar da pandemia e a escassez de dispositivos médicos no mercado nacional, veio demonstrar que em Portugal existe capacidade para a investigação, desenvolvimento e produção deste tipo de produtos.

Foram muitas as respostas apresentadas quer pela academia, quer pela indústria nacional, para apoiar a saúde da população, no entanto, verificámos também que nem todos estavam preparados para compreender e respeitar as exigências que a regulação dos dispositivos médicos exige, para bem da saúde pública.

De realçar o papel fundamental do INFARMED na coordenação das iniciativas e atividades desenvolvidas pelos vários atores, assegurando que as mesmas se pautavam pelos mais elevados padrões de qualidade garantindo assim um nível permanentemente elevado de proteção da saúde e de segurança do mercado nacional.

\section{Conclusão}

A agilização, a simplificação e a derrogação dos procedimentos de avaliação de conformidade prevista na Recomendação da Comissão (UE) 2020/403 da Comissão e no Decreto-Lei n. ${ }^{\circ}$ 14-E/2020 aplica-se apenas a casos excecionais e de forma temporária para dispositivos colocados no mercado nacional.

No período máximo de seis meses, os fabricantes terão de decidir se pretendem colocar no mercado estes produtos de acordo com a legislação de harmonização da União Europeia e, nessa situação, o fabricante deverá provar à autoridade de fiscalização (INFARMED) 
harmonization legislation and, in that situation, the manufacturer must prove to the supervisory authority (INFARMED) that it has initiated the necessary procedures for product conformity assessment under applicable law.

In order to support investment in health and economic development, the production activity of the national industry must be in accordance with best practices and European legislation, while guaranteeing the conformity of the devices it manufactures with safety and performance requirements.

It is also important that the research carried out by the academy is in accordance with the rules established in European regulatory diplomas, transposed into national legislation, as a necessary factor for industrial scale production.

In my opinion, it would be a mistake that all of the work developed, the cooperation of the various entities involved (Ministry of Economy, Ministry of Science, Technology and Higher Education, Ministry of Health and National Industry) and the respect and recognition by INFARMED, which over the years have has asserted as a competent authority of excellence at the national and international level, not to have a positive impact on the development of the Portuguese production system, which, while ensuring its compliance with safety and performance requirements, and according to best practices and European legislation, our national response allows an opportunity to promote international recognition of Portuguese industry and facilitate access to other markets.

In order to enhance the ideas and gains that resulted from the response to the crisis, a detailed analysis of all the variables included in this opinion article and the presentation of proposals for improvement, in the perspective of defining a national strategic vision in the area of health sciences and in particular in the area of the development and production of medical devices, will be the object of a study to be published in due course.

\section{Conflict of Interests}

The author declares there are no financial and/or personal relationships that could present a potential conflict of interests

The author declares that she was an INFARMED manager until 2012. que deu início aos procedimentos necessários para a avaliação da conformidade dos produtos nos termos da legislação aplicável.

Para dar apoio ao investimento em saúde e ao desenvolvimento económico, a atividade de produção da indústria nacional deverá estar de acordo com as melhores práticas e com a legislação europeia, enquanto garante da conformidade dos dispositivos que fabrica, com os requisitos de segurança e de desempenho.

É também importante que a investigação realizada pela academia esteja em conformidade com as regras estabelecidas nos diplomas regulamentares Europeus, transpostos para a legislação nacional, fator necessário para a produção à escala industrial.

$\mathrm{Na}$ minha opinião, seria um erro que todo o trabalho desenvolvido, a cooperação das várias entidades envolvidas (Ministério da Economia, Ministério da Ciência, Tecnologia e Ensino Superior, Ministério da Saúde e Indústria Nacional) e o respeito e reconhecimento pelo INFARMED, que ao longo dos anos se tem afirmado como autoridade competente de excelência a nível nacional e internacional, não tivessem impacto positivo no desenvolvimento do sistema produtivo português, que de acordo com as melhores práticas e com a legislação europeia, enquanto garante da sua conformidade com os requisitos de segurança e desempenho, permita promover o reconhecimento internacional da indústria nacional e o fácil acesso a outros mercados.

Com o objetivo de potencializar as ideias e ganhos decorrentes da resposta à crise, a análise detalhada de todas as variáveis que incluí neste artigo de opinião e a apresentação de propostas de melhoria, na perspetiva da definição de uma visão estratégica nacional na área das ciências de saúde e em particular na área do desenvolvimento e produção de dipositivos médicos, será objeto de estudo a publicar oportunamente.

\section{Conflito de Interesses}

O autor declara que não há relações financeiras e/ou pessoais que possam representar um potencial conflito de interesses

O autor declara que foi dirigente do INFARMED até 2012 


\section{References / Referências}

1. Parlamento Europeu e do Conselho. Directiva n. ${ }^{\circ}$ 93/42/CEE, do Conselho, de 14 de Junho de 1943. J Oficial Comunidades Europeias. L 196 (12.07.93) 0001-0047.

2. Parlamento Europeu e do Conselho. Directiva n. ${ }^{\circ}$ 98/79/CE, do Parlamento Europeu e do Conselho, de 27 de Outubro de 1998 . J Oficial Comunidades Europeias. L 331 (7.12.1998) 0001-0037.

3. Decreto-Lei n. ${ }^{\circ}$ 273/95, de 23 de Outubro, Diário da República n. ${ }^{\circ}$ 245/1995, Série I-A de 1995-10-23.

4. Decreto-Lei n. ${ }^{\circ}$ 189/2000, de 12 de Agosto, Diário da República n. ${ }^{\circ}$ 186/2000, Série I-A de 2000-08-12.

5. Decreto-Lei n. ${ }^{\circ}$ 145/2009, de 17 de Junho, Diário da República n. ${ }^{\circ} 115 / 2009$, Série I de 2009-06-17.

6. Parlamento Europeu e do Conselho. Directiva n. ${ }^{\circ}$ 2007/47/ CE, do Parlamento Europeu e do Conselho, de 5 de Setembro. J Oficial Comunidades Europeias. L 247 (21.9.2007), 21-55

7. Parlamento Europeu e do Conselho. Regulamento (UE) 2017/745 do Parlamento Europeu e do Conselho de 5 de abril de 2017 . J Oficial Comunidades Europeias L 117 (5.5.2017), 1-175

8. Parlamento Europeu e do Conselho. Regulamento (UE) 2017/746 do Parlamento Europeu e do Conselho, de 5 de abril de 2017. J Oficial Comunidades Europeias. L 117 (5.5.2017), 176-332

9. Council Resolution of 7 May 1985 on a new approach to technical harmonization and standards, Official Journal C 136, 04/06/1985 P. 0001 - 000910. Decreto-Lei n. ${ }^{\circ}$ 76/2006 de 27 de Março, Diário da República n. ${ }^{\circ}$ 61/2006, Série I-A de 2006-03-27

10. Decreto-Lei n. ${ }^{\circ}$ 76/2006 de 27 de Março, Diário da República n. ${ }^{\circ}$ 61/2006, Série I-A de 2006-03-27

11. European Commission. Communication from the Commission Guidelines on the adoption of Union-wide derogations for medical devices in accordance with Article 59 of Regulation (EU) 2017/745 2020/C 171/01, C/2020/3347, OJ C 171, 19.5.2020, p. 1-4. [accessed July]. Available from: https://eur-lex.europa.eu/legal- content/EN/TXT/?uri=CELEX\%3A52020XC0519\%2801\%29

12. Decreto-Lei n. ${ }^{\circ}$ 14-E/2020 de 13 de abril, Diário da República n. ${ }^{\circ}$ 72/2020, $2^{\circ}$ Suplemento, Série I de 2020-04-13

13. Direção Geral da Saúde, INFARMED. Norma conjunta INFARMED/DGS sobre equipamentos de proteção individual. 22/03/2020. [acedido Julho 2020] Disponível em: https://www. dgs.pt/directrizes-da-dgs/normas-e-circulares-normativas/ norma-n-0032020-de19032020-pdf.aspx

14. INFARMED, I.P. Informação sobre máscaras cirúrgicas Dispositivos médicos vs. Respiradores (30/03/2020). [acedido Julho 2020] Disponível em https://www.infarmed.pt/ documents/15786/3584301/Mascaras+Versus+EPIs/733267cf- 46d3-c102-bc19-bb5e1b6048a0

15. Autoridade de Segurança Alimentar e Económica. Informação atualizada (em articulação com a ASAE) sobre Importação de Dispositivos Médicos e Equipamentos de Proteção Individual no contexto da Pandemia COVID-19 (07/04/2020). [acedido Julho 2020] Disponível em: https://www.asae.gov.pt/covid-19-asae.aspx

16. Direção Geral da Saúde. Participação na elaboração de informação sobre uso de máscaras na comunidade. [acedido Julho 2020] Disponível em: https://covid19.min-saude.pt/dgs- publica-informacoes-sobre-o-uso-de-mascaras-na-comunidade/

17. Máscaras destinadas à utilização no âmbito da COVID-19 (14/04/2020). [acedido Julho 2020] Disponível em: https://www.infarmed.pt/ web/infarmed/infarmed/-/journal_content/56/15786/3632902

18. INFARMED, I.P. Fabrico, importação, colocação e disponibilização no mercado nacional de dispositivos médicos (DM) para efeitos de prevenção do contágio do novo coronavírus (SARS-CoV-2) - Listas dos referenciais normativos (21/04/2020). [acedido Julho 2020] Disponível em: https://www.infarmed.pt/web/infarmed/infarmed/-/journal_content/56/15786/3654236

19. INFARMED, I.P. Autoridade de Segurança Alimentar e Económica. Importação e fabric de dispositivos médicos e equipamentos de proteção individual no contexto da pandemia COVID-19 (DL 14E/2020) (28/04/2020) (documento elaborado, em parceria, pelo Infarmed e pela ASAE). [acedido Maio 2020] Disponível em: https://www.infarmed.pt/ documents/15786/3584301/ Importa $\% \mathrm{C} 3 \% \mathrm{~A} 7 \% \mathrm{C} 3 \% \mathrm{~A} 3 \mathrm{o}+\mathrm{de}+\mathrm{Di}$ spositivos $+\mathrm{M} \% \mathrm{C} 3 \% \mathrm{~A} 9 \mathrm{dicos}+\mathrm{e}+$ Equipamentos + de + Prote $\% \mathrm{C} 3 \% \mathrm{~A} 7 \% \mathrm{C} 3 \% \mathrm{~A} 3 \mathrm{o}+\mathrm{Individual}+$ no + contexto+da+Pandemia+COVID-19/8afa1c4a-2705-a445-8d3d-0b434fae8e03?version=1.1

20. INFARMED, I.P. Adiamento da data de aplicação do Regulamento dos Dispositivos Médicos, devido aos constrangimentos originados pela Pandemia (24/04/2020). [acedido Maio 2020] Disponível em: https://www.infarmed.pt/ web/infarmed/infarmed/-/journal_content $/ 56 / 15786 / 3661242$

21. INFARMED, I.P. Máscaras: normas aplicáveis e tipologia (14/05/2020). [acedido Julho 2020] Disponível em: Máscaras: normas aplicáveis e tipologia $(14 / 05 / 2020)$.

22. INFARMED, I.P. Infografia - Máscaras destinadas a utilização no âmbito da COVID-19 (14/05/2020). [acedido Julho 2020] Disponível em: https://www.infarmed.pt/web/infarmed/ infarmed/-/journal_content/56/15786/3685202

23. INFARMED, I.P. Comunicado de Imprensa - Aquisição de medicamentos EPI e DM no âmbito da pandemia COVID-19 (07/04/2020). [acedido Julho 2020] Disponível em: https:// www.infarmed.pt/web/infarmed/infarmed/-/journal_content/56/15786/3623218

24. INFARMED, I.P. Procedimento especial de avaliação de dispositivos médicos no âmbito COVID-19 - Ventiladores (21/04/2020). [acedido Julho 2020] Disponível em: https:// www.infarmed.pt/web/infarmed/infarmed/-/journal_content/56/15786/3654738

25. https://www.infarmed.pt/

26. https://ec.europa.eu/health/md_sector/overview_en

27. https://ec.europa.eu/commission/presscorner/detail/en/IP_20_502 